\title{
The Role Of Indigenous Peoples In North Maluku In Maintaining Environmental Sustainability
}

\author{
Samian \\ Program of Law \\ Universitas Borobudur \\ Jakarta, Indonesia \\ asamian462@gmail.com
}

\author{
Faisal Santiago \\ Faculty of Law \\ Universitas Borobudur \\ Jakarta, Indonesia \\ faisalsantiago@borobudur.ac.id
}

\begin{abstract}
Indigenous peoples and local communities are among the best environmental guards. Their livelihoods and culture depend on forests, dean water and other natural resources, so they have high motivation to manage their land sustainably. The problems raised by this research: how is the effectiveness of customary law in protecting the environment and the position of customary law of sea law against positive law in Indonesia, especially related to environmental issues? The condusion is that the role of indigenous peoples with their customary law such as sasi customary in preserving the environment is very effective because with the existence of customary law, the people do not dare to take natural resources before the open time of sasi. It is the fact that from these two laws that are customary law and positive law have an interrelated position with one another. So it can be said that customary law can be used to protect the existing natural resources.
\end{abstract}

Keywords- role, indigenous peoples, environmental sustainability

\section{INTRODUCTION}

Earth belongs to us together, so its sustainability is a shared responsibility. Environmental preservation is a necessity that can not be delayed anymore. Environmental preservation is also not only the responsibility of the government, but the responsibility of all. Currently, many people seem indifferent in maintaining environmental sustainability. Ironically, environmental destruction is done by those who have higher education or their business entities. In contrast to indigenous peoples who tend to be labeled as underdeveloped and primitive societies, but in preserving the environment, their role is indisputable.

Indigenous peoples and local communities are among the best environmental guards. Their livelihoods and culture depend on forests, clean water and other natural resources, so they have high motivation to manage their land sustainably. Indigenous Peoples According to the AMAN (Alliance of Indigenous Peoples of the Archipelago) at the First Congress of 1999, are: "Communities that live on the basis of ancestral origins on an indigenous territory, which has sovereignty over land and natural wealth, social life cultures regulated by customary law and customary institutions that manage the survival of their communities ".

Indigenous and tribal peoples according to Law No.32 / 2009 on Environmental Protection and Management, CHAPTER I Article 1 clause 31 are: Indigenous and tribal peoples are a group of people who descend to settle in certain geographical areas because of the ties to the ancestral origins, environment, and the value system that determines economic, political, social, and legal order. Customary Law Community has various wisdom in managing the environment, so it has an important role in the effort of environmental conservation. In addition, the customary law community is hereditary trying to preserve the environment by way of customary forest and surrounding, and not cut trees indiscriminately. They still maintain the cultural values to exist in their environment, as well as in interacting with the surrounding community.

Indirectly, indigenous and tribal peoples have implemented the mandate of Law No.32 of 2009 on Environ mental Protection and Management, artic le 67 where it says that, "Every person has the obligation to preserve the function of the environment and control pollution and / or environmental damage."

In this research, the writer will appoint one of customary law community, that is custom law society residing in North Maluku. The authors chose indigenous and tribal peoples in North Maluku because the authors were interested in the customary law of customary Sasi of Sea (Sasi is a tradition of the people of the country in Maluku, to preserve certain potential outcomes) in their custom, where the customary law of Sea Sasi is a form of protection and environmental management of their living environment.

Efforts to conserve the environment for the people of Maluku has been carried out since the first, which are done for generations. This will be evidenced by one of the cultural communities of Maluku that prohibit the taking of certain potential results with or without damaging the environment. Prohibition activities to take these potential outcomes by the people of Maluku are known as "SASI". Sasi is a tradition of the people of the country in Maluku, to preserve certain potential outcomes. When sasi is implemented, the community is prohibited from picking certain fruits on land and harvesting certain results from the sea during the time period set by the village government (Cooley, 1987).

The role of sasi allows natural resources to continue to grow and develop. In other words, biological and vegetable natural resources need to be preserved within a certain period to restore growth and development in order to achieve satisfactory results (Pattinama \& Patipelohy, 2003). Historical sasi in Maluku has existed since time immemorial and is a joint commitment both by society and by customary 
leaders, public figures and religious leaders. It is based on the awareness that without their environment can not live properly, so sasi must be maintained by generation to generation. In the maintenance of natural resources there are rules that have been applied both in writing and not written, which is known as the "Law of Sasi". Sasi Law, which is a local legal system containing a prohibition and the necessity to pluck or take the potential of natural resources of a certain kind for a short period of time (Pattinama \& Patipelohy, 2003).

All maintenance of natural resources is supervised by customary institutions such as kings, chiefs of soa, saniri, kewang and marinyo. But the more important role in the maintenance of these natural resources is the kewang and the children of kewang who function as the forest police. Kewang plays an important role, because it is one ele ment of government that is responsible for maintaining the environment both on land and at sea from the hands of irresponsible people (Lakolo, 1988).

\section{DISCUSSION}

\section{A. Environmental Regulation Under Customary Law}

In addition to the above regulations there are also customary law regulations issued to regulate the utilization and management of natural resources. This regulation is a form of awareness of village government and even the community to maintain and preserve their natural environment. The rule or norm is Sasi.

Sasi is a tradition of society that has substantive legal value that is a temporary prohibition to not take the forest products and sea products up to a certain time. Sasi can be said to have legal value, because it has norms or rules relating to the manner, custom, behavior, and custom which contains the elements of ethics and norms. The substantial legal values in the sasi system as the core of customary law are as follows:

a. The right use of a person's rights according to the time specified.

b. Prevent the occurrence of disputes between fellow residents of the country.

c. Maintenance and conservation of natural environment (sea/land) for the improvement of common prosperity.

d. Obligation to indulge seafood and land products.

The role of Sasi is to provide security for natural resources and environment as well as to educate and shape the attitude and behavior of the society which is an effort to maintain the living ethics of the community including the effort of equitable distribution and income from natural resources to the entire community or local people. Because sasi has a role as a cultural value of society, it is necessary to maintain its sustainability. Types of sasi apply in Maluku, among others:

\section{General Sasi}

is a sasi applied by all villagers. General Sasi is divided into 2 , namely:

a. Sasi of water, consisting of:

1) Sasi of sea
Is a sasi covering coastal areas and sea including village of Peruanan. This means any sea content deemed important by the local community, depending on the economic value of the seafood. The first set by the sasi is a special fish. This also includes certain types of fish that usually move in groups such as lompa fish. If one group has entered one harbor then the community is forbidden to arrest him. Since then the sasi came into effect. Examples of marine sasi, such as: bialola (seashell), seaweed, pearl, and fish.

\section{2) Sasi of river}

is Sasi that set about things that should not be done multiplied. For example when the fish lompa has entered into the river, people are forbidden to interfere or catch him. Communities are prohibited from washing kitchen materials multiplied, men are prohibited from bathing mixed with women, forbidden to wash clothes or any laundry materials through the place of drinking water, motor boats or type of Speed Boat that enter into the river should not turn on the engine, wooden trees on the river edge around the sasi location should not be logged except sago trees. Examples of river sasi, such as: lompa fish on the is land of Haruku.

b. Sasi of land, consisting of:

\section{1) Sasi offorest}

is a sasi covering a wide range of objects that exist on the land. Usually in the sasi is a plant, whether planted by people or which grow by themselves. The plants are plantation crops that meet daily needs. Examples of forest sasi, such as: coconut, nutmeg, fruits, rattan, resin and cloves.

\section{2) Animal Sasi}

is a specific animal in the forest location is protected and arrested in accordance with the needs of the local community. For example we can find in the country (village) Titawai is a sasi to protect animals / animals kusu (kus-kus). This animal is now beginning to be rare with regard to deforestation for planting or logging for various development needs.

As is known, animals of "kus kus" is living in certain trees that at the same time is a source of food such as walnut trees, gondal trees, banyan tree, Lenggua tree, and others.

2. Private Sasi

It is a sasi imposed by a person on something he already owns and reported to the village government. Private Sasi is only applicable for forest sasi.

3. Sasi of Religion

Is the sasi set by the religious opener. This sasi is also called spiritual sasi or sasi belief because based on trust. It is related to the orig inal beliefs or religions that live in society when they have not yet formally embraced Islam and Christianity. Sasi belief is closely related to public belief in the power of ancestral spirits, and the power of the universe in the past. Some form 
of real and sasi this is sasi over labuhan (ocean) which done in period 1-2 months. Orig inally the sasi period of the sea that was made as a party was declared closed because there were people drowning around it. Similarly, if there are people who fall from a tree or die in the forest then the area around the forest declared by sasi within 1-2 months as well. People believe that if there is an accident in the sea or in the forest then for a while the spirits of the dead are wandering around looking for a place to stay so that for a while anyone who is still alive is prohibited to go there because it can be woe or get other disturbance.

\section{4. $\quad$ Sasi Negeri / Sasi Kampong}

It is a prohibition that regulates the social life between people in the village. As forbidden to make rebut on the night of the week and if you want to make a show at night in the form of parties and others must get permission from Saniri country. On Sundays people are forbidden to the sea or to the forest unless there is an important need, but must get permission from kewang.People banned roasting the roof or burning grass, shell, etc. on the highway and hanging clothes on the fence. Women are forbidden to climb trees with inappropriate clothing, and when they come home from river are forbiden to wear clothes. Men are forbidden to wear sarongs during the day and should not wear underwear or salele towels and walk on the highway.

\section{Babaliang Sasi}

Is a form of domestic sasi for the improvement of the welfare of the children of the country. Resident Riedel in the years 1880 - 1883 tried hard to remove sasi babaliang without a clear reason. Riedel, among others, prohibits the implementation of sanctioning of babaliang, prohibiting the existence of head of kewang, prohibiting the enactment of reglement kewang. This type of sasi is only found on the island of Ambon and is carried out in the countries of the is land in different ways.

Sasi Babaliang can be described as follows: the number of state children (who have money) is granted the right to co-operate for a period of 1 year buying the proceeds from the hamlets that are worn. The purchase of the hamlets produced by the sasi was purchased through the country. The hamlets that are about to be worn and the villages that are not subject to sasi have been predetermined in the public meeting. The buyer team has also been determined and is under police surveillance. The police and the buyer's team have the same authority as the kewang and kewang children to check whether the village is always clean and may impose fines for violation of the sasi.

\section{B. Regulation Governing Customary Law}

From the above explanation can be put forward some rules of customary law ever enacted and become a reference for the manufacture of rules of sasi and kewang in countries in Maluku, among others (Soekanto, 2003):
The Dutch government's regimes of 1915 - 1922 series No. 45 about sasi. Registrasi Te Paperoe (State Paper Paper Registration).

Consists of 6 articles that contain about the deeds are prohibited and required. Especially with regard to prohibited and required activities, several articles are known as:

c. chapter (a) "all fru its are taken with its place". who are punished with 9 times 9 cent, everyone is taken (up).

1) Any coconut fruit outside the permit of kewang though in its own hamlet.

2) All the walnuts

3) All the areca nut

4) All durian fruit and others.

While the young coconut is forbidden altogether, if it is made then the guilty in the law because a:

1) if each person 9 times 9 cent

2) if people are 9 times 90 cent

In the use of the sick or on the way through the road or hamlet. Where coconut trees are found, this is granted as long as it is caught by the head or kewang that is nearby in that place.

Take all the real fru its in the numbers 1-3 to be notified at kewang so that it is taken under the eyes of kewang.

b. clause (b) "that the land and ports of the country shall be kept or used of the people of their own country."

In law with a fine of 9 times 90 cent:

All the people who enter the country's forests and harbors of state land.

1) take the wood for the houses.

2) Crowded with tools, or tides of clove season, if the actual acts of the country's own child 1/9 of the above sentence.

3) searching with a net in the harbor for the country's children.

4) Hal bore (with pois on) if real act of child of own country $1 / 9$ of punishment above. All the tools or towers used by the merchant are taken, stored and kept to the authorities for the proofs to be exhausted, checked to the owner.

The Government of the Dutch East Indies 18 February 1863 series R no. 43 on the duties of the Regents of Van de negerij ema (State ema's state regulatory body).

The number of articles there are 25 pieces. This regulation of sasi was signed by King M. Leimena. In this Reglement are known several chapters, namely:

\section{d. chapter 21:}

in the heat of six months there shall be provided in the houses of 12 bases of the bulow guarded by the ponoh with the water up and down. Kewang distracted whoever is not overwhelmed he will get a fine of 50 cent to kewang.

\section{e. Article 22}

"There shall be forbidden to the merchants and others the country shall not be on hela dudeso or the ropes of pigs or deer in wijk or hamlets where there is an ordinary human bitch, and where there are kahidopang trees, may do so but in 
the upstream must be permission from the head of kewang so that it's head of kewang love to know the people of the country and the village master and the gamers can know which rope or dudeso is sitting in the village, lest he catch the people of the country or the village die and pay the fee to kewang.

It turns out that the contents of the ema state up to now are still known, although some have undergone some changes. This is admittedly by the adat leaders in ema country according to their maintenance and supervision of sasi and sanction violations, including: of:

sasi activities that apply to land transportation, consisting

a. forest sasi, namely:

1) coconut sasi, leaf of rumbia or sago and gaba-gaba.

2) sasi daun enau.

3) bamboo sauce and bamboo shoots.

4) sasi against the felling of protective trees, such as: felling of durian, walnut, mango, and rambutan trees.

5) sasi to the cloves and nutmeg.

b. sanctions and violations of sasi, consisting of:

1) forest $s a s i$, in the form of:

1) young coconuts 1 (one) fruit fined $=\mathrm{Rp} 1000$, -

2) dry coconut 1 (one) fruit fined $=\mathrm{Rp} 1000$, -

3) taking bamboo shoots without permits, 1 (one) rod fined $=\operatorname{Rp} 500,-$

4) felling of protective trees, such as durian, walnut, mango, and rambutan trees fined $=\mathrm{Rp} 10.000$, -

5) theft of cloves and nutmeg yields which are the largest crops of the country ema fined $=\mathrm{Rp}$ 10.000,-

For those who do not heed the sanction of this fine it will be subject to alternative sanctions or substitution sanctions which is the heaviest sanction in the country ema, namely sanctions in the form of whips with rattan and sanctions is adjusted to the level and violation of the sasi happens, which is the result of $R p 500$, - and $R p 1000$, - shall be punished by 2 (two) to 3 (three) times and a profit sharing of Rp 10.000, whipped 5 (five) times.

What is contained in the law of sasi as found in ema country has substantive value because it supports the rule of law adat. It is said that because the use of sasi law is to curb the community in the utilization of land and sea environments.

The Dutch East Indies Government Regulation Year 1870 Series R no. 42 on the regulatory authority of Van de negerij porto.

In the land of porto Saparua island rules of authority made in the year 1870 determined some rules that must be adhered to by special residents in the maintenance of social order. For example as follows: whoever argues and issues dirty words or insults and profanity will be fined 50 (fifty) cents. Where the money is taken for the state treasury. When the day comes and the children are caught by the zest for not attending Sunday school or mentioning the name of the god in vain the child by authority will be brought before the king to be given a warning.

If a person is caught red-handed by a theft of another person's plantation, then the thief must hand over his machete to the head of kewang. Subsequently he was escorted by the head of the civil service to the country for questioning. Similarly, if a person suspects a person who comes home from the forest while carry ing something, then the right to check on the person's basket. Whenever the pers on refuses to be examined, the right shall be entitled to take his machete and together with the owner of the basket to the king for questioning. Unfortunately this function of kewang is no longer in line with the emergence of sasi made through the church and a change in the system of customary state government.

The Government of the Dutch East Indies R series. 44 on Het Recht Van Sasi in de Molukken of 1921.

In addition to the recognition of a sasi from the Dutch East Indies government. At the time of the Indonesian government are also known some rules of law and sasi regulations, such as:

a. Secure Sasi Haru Ukai and the kewang institutions of Haruku state.

b. Sasi Rules of Paperu State.

c. Sasi Rules of Ihamahu State.

d. Sasi Rules and Kewang of Itawaka State.

e. Sasi Rules of Amahai State.

f. Sea Sasi Rules and Kewang of Haria State.

g. State Kewang Regulation of Tulehu no. 1 Year of1980.

When examined in depth then the meaning of sasi can be said as the values of substantive law of the sasi institution. The values are:

a. The use of a person's right according to the time specified to reap the rewards from his or her hamlet.

b. Prevent the occurrence of disputes (land and water) between fellow citizens of the country and between residents of the bordering country.

c. Maintenance and conservation of the natural environment (sea and land) for the improvement of common prosperity.

d. Obligation to pamper plants and living creatures at sea.

e. Avoid accidents for women.

f. Reduce the likelihood of a crime in the form of theft.

Based on the above description the authors argue that the role of customary law and environmental law is very closely and mutually supportive, it can be seen in legislation that is UUD 45 article 33 paragraph 3 and Basic Agrarian Law (UUPA) Article 5 and Article 16 paragraph 2 and Law No. 23 on environmental management in Article 9 paragraph 3, article 18 paragraph 1, Article 22 paragraph 3, and Article 25 paragraph 1. If reviewed from those articles, they have a relationship or attachment in terms of protection of environmental sustainability life. The authors say so, because in those chapters there are things that explain about:

a. the use of the environment from and by the citizen or society itself 
b. preservation or protection of the use of the products of natural resources in the living environment itself, and

c. sanctions against possible or actual violations of the abuse of natural resource products.

\section{Customs Law of sasi and National Regulations}

Having links to several national legislation regulating the preservation and protection of natural resources. The rules are:

\section{1) a. UU no. 31 Year of 2004 on Fisheries.}

Article 8 paragraph 1: "Every person shall be prohibited from fishing or cultivating fish by means of chemical, biological materials, explosives, tools and / or means, and / or buildings which may be detrimental and / or endanger the preservation of fish's natural resources and / or its environment in the territory of fisheries management of the Republic of Indonesia."

Article 9: "Every person shall be prohibited from possessing, dominating, carrying and / or using fishing vessels in the territory of fisheries management of the Republic of Indonesia:

a. fishing gear and / or fishing aids that are not in accordance with the specified size;

b. fishing gear not conforming to the requirements or standards specified for a particular type of equip ment; and / or

c. fishing equipment which is prohibited.

Article 12 paragraph 1: "Every person shall be prohibited from committing acts which cause pollution and / or damage of fish resources and / or environment in the territory of fisheries management of the Republic of Indonesia.

\section{2) b.UU no. 41 of 1999 on Forestry}

Article 18 paragraph 1: the government establishes and maintains sufficient forest area and forest close for each watershed and / or island, in order to optimize the environmental benefits, social benefits, and economic benefits of local communities.

Article 33 Paragraph 1: The effort to utilize the forest products includes activities of planting, maintaining, harvesting, managing, and marketing forest products .

Article 37 paragraph 1: the utilization of customary forests shall be carried out by the indigenous peoples concerned in accordance with their functions

paragraph 2: the utilization of customary and conservative protected forests can be carried out as long as it does not interfere with its function.

Article 46: the implementation of forest protection and nature conservation aims to safeguard the forest, forest area and its environment, so that the function of protection, function of conservation, and function of production is achieved optimally and sustainably.

Article 47: protection of forests and forest areas is an attempt to: a. prevent and limit the destruction of forests, forest areas and forest products caused by human actions, livestock, fire, natural resources, pests, and diseases;

b. maintain and safeguard the rights of countries, communities and individuals on forests, forest areas, forest products, investments and tools related to forest management.

Article 67 paragraph 1: customary law communities insofar as they still exist and are acknowledged to be entitled to:

a. collect forest products for the fulfillment of the daily needs of the indigenous peoples concerned;

b. conduct forest management activities under customary law and does not conflict with the law; and

c. gain empowerment in order to improve welfare.

The Effectiveness of Customary Law of Sasi in Maintaining the Environment and Position of Customary Law of Sea Sasi on Positive Law in Indonesia Especially Related to Environmental Problem.

From the results of research that the authors obtained from the Eti Village, West Seram District ,West Seram regency, then the sasi customary law village that temporary on the run in this case is sea sasi. Because in the presence of sea sasi can maintain the preservation of marine natural resources such as sea cucumbers, bialola, and fish to avoid extinction. In some places of customary villages in Maluku have not run sea sasi customary again, so the existing natural resources are not preserved anymore. As a result, some of the marine natural resources in the village of Eti are no longer found in otherindigenous villages in Maluku province.

In Eti village, customary law in protecting the environment especially the sea is very effective because with the existence of this customary law, the community does not dare to take natural resources before time for sasi. In Eti village, the implementation of sasi is the same as the Maluku community in general, where after the implementation period of the sasi, the sasi zone also impose sanctions on the violation sasi. Sasi zone is along the coast which is the right of the village and towards the sea, this zone starts from the lowest tide to a depth of 25 meters. Thus, a zone is a limited area for the utilization of natural resources that is fully regulated through marine customary regulations. Natural resources of the sea in the village of Eti protected by customary law of sea sasi namely sea cucumber, bialola, and several types of fish.

Sasi is a prohibition to harvest certain resources (marine and terrestrial biodiversity) within the set time. Based on the habitat inhabited, this sasi is divided into land sasi and sea sasi. Sasi can also be grouped according to the kind of commodities that are harmonized such as: lola sasi, cucumber sauce, coconut sasi, cloves sasi, nutmeg sasi. Sasi is aimed to arrange all the produce (land and water) that exist in the territory of the country, either in the yard itself or in the plantation or lading area, all will get the same treatment. Sasi is results of the decree (decision) of the king and get the agreement of all citizens who certainly bind all the citizens, and there are sanctions if citizens try to violate. During this time the sasi can run well because of the group of people 
who keep the agreement of sasi (kewang) and there is a belief in the community if the agreement is broken, it will give rise to bad (bad effect) for the violation of sasi (Ellias, 2008).

The purpose of the sasi according to some residents in the village of Eti is to save the plants or fruits and seafood so as not to be harvested before the harvest or really worth the harvest, so get maximum results (prevent loss of farmers and fishermen). Sasi also aims to avoid theft, because after enacted sasi there will be a group of people who maintain the area of sasi called kewang.

There are interesting things to be studied in relation to this issue of effectiveness, because although rarely found any violations but there are still violations that occur in the indigenous communities. In Indigenous Peoples in Eti Village there have been cases of stealing sea cucumbers, this happens because the people in Eti village are less aware of the purpose of the implementation of customs so that the exploitation of natural resources is done excessively without considering the impact of such excessive exploitation even though there are sanctions enacted. This case should be the theft of sea cucumber special attention from the elders / elders in keeping the village so that the case of stealing sea cucumber is not happening again.

The position of customary law of sea law against positive law in Indonesia is particularly related to environmental issues. The law has something to do with the environment, because indirectly it can provide protection to the existing natural resources in order to preserve the area.

Customary law is part of custom or custom, it can be said that customary law is a concrete form of legal consciousness, especially in societies with simple social and cultural structures. Customary law regulates legal relationships (rights and obligations) between pers ons or organizations in an indigenous communion with the natural resources of their territory.

In connection with the above, then from customary law came the concept of customary rights. Basically customary rights can be categorized as the right of indigenous peoples to control, own, utilize and manage natural resources in its territory (Pelokila \& Zakaria, 1998). From this description it can be said that customary rights are the indigenous rights of indigenous peoples in line with the presence and growth of the community itself over the area of their residence with various natural resources and are entitled to be managed and utilized by the local people for their welfare and survival.

Positive law is the law that regulates the protection of natural resources. Positive law in Indonesia related to environmental issues such as: Law no. 31 of 2004 on Fisheries, Law no. 41 of 1999 on Forestry, and Law no. 23 of 1997 on Environmental Management. It turns out that both laws are customary law and positive law has an interrelated position between one another. So that with both these laws can be used to protect the existing natural resources.

The rules of customary law of sea and water in Desa Eti which contain: a. The ban on catching and / or picking up certain fish species, sea cucumbers, lola and other marine products by using fishing gear such as fishing rods, kalawai, spears, machetes, nets, and the like on coastal areas, the location of the conserves, sea cucumbers, lola and other marine products due to the prohibited use of fishing gear as mentioned earlier makes the catch little so that the conservation of marine resources can occur. Like Tuhaha Village in Saparua Island, to catch the fishing must use simple tools, such as hook so it can not catch much. Fishing with nets is not allowed at all.

b. The prohibition of fishing by using pois on or bore roots or other chemicals that can damage marine habitat and coral reefs is prohibited from using poison or roots of bore or other chemicals as it may damage the preservation of other marine habitats. As in Kei Village, Southeast Maluku Regency at the time of sasi opening of fish and snail fish, poison or bore roots are forbidden to be used.

c. Restrictions on damaging coral reefs and other marine biota, such as taking root of bahar, sponges and other marine biota within the prohibited territory of the country, when taking root of bahar, sponges and other marine biota can damage coral reefs because of sponges and biota the sea there are many cracks in the rocks. Like the village of A meth in Nusa Laut Island Central Maluku community is prohibited to take sponge as it can damage coral reefs

d. Restrictions on cutting, cutting down, harvesting and destruction of mangroves and crops in coastal areas within the country's territory, are prohibited from destroying mangrove forests and adjacent crops as they may lead to erosion of coastline / abrasion and breeding grounds to be nonexistent such as Islam Sirisori Village in Saparua Island, community is prohibited to destroy or cut down the mangrove forest because it can lead to the fish catch becomes reduced

e. The prohibition of taking sand, rocks, corals and gravel without the permission of the government of the country on the coastal and ocean areas within the territory of a country, aims to maintain sustainability around the beach.

\section{Sanctions Against Violation of Sasi.}

Similar to other customs, sanctions for violations of customary law are carried out by the ruler of the land and the ancestral spirits. The most severe and dreaded sanctions in the past were the sanctions given by the ancestral spirits. Therefore people are very afraid of breaking sasi. Whenever there is a person who breaches the sasi is to take the sea tattooing or seafood products during the closing session, the punishment given by the government of the country, namely the king and the state apparatus to the offender is to be arrested, shown before the public and received other physical punishment such as whips, imposed fines, forced labor and ostracized from the middle of public life. Punishment is not too heavy as punishment that will be given by spirits or spirits of tete nene ancestors, among others: sickly children 
continuously and eventually died so that the family does not have a descendant. The local term is mataruma close.

In the closing session each pers on must keep or be aware of himself so as not to make things contradict until finally get a reprimand and punishment from the kewang and children of kewang. Meanwhile, the atmosphere around the forest and labuhan (ocean) becomes calm and quiet. Kewang and kewang child will keep on going to check if anyone is breaking the sasi or not. Residents of the country are still allowed into the forest or sea to take food but all that takes place calmly and only come to places that do not become sasi region. Fish and food of plantation contents are only taken for food purposes should not be more.

For example in the ULLATH country in central Maluku if there is a sasi close but there is someone who because of the urgency has to take the result (which temporarily in sasi, eg. coconut) from his plantation after obtaining permission fro $m$ the head of kewang then concerned in the mandatory to plant a coconut tree again for replacing coconut-fruit that has been picked. The custom is still running until now even though the country's sasi has been replaced by the church sasi. Similarly, when the closing period runs and because there is forced to have someone to go to the forest then when he walks, he must walk quietly noisy / make noise while his face down directed to the ground. Women who want to go to the forest are forbidden to cover their heads with a white towel or cloth because it is considered white color is shap and blinding.

The law of sasi is a number of regulations containing a prohibition with a fine penalty. The law of sasi is divided into material law which is the subject of the criminal act, what kind of criminal can be applied to the person doing the acts contrary to the Regulation sasi. Whereas the formal law of sasi is a number of regulations which contain the means of authority to use its authority to apply the criminal, but it also aims to protect nature with everything that exists above it from the destruction caused by human acts. In other words, sasi keeps the mark of the fellowship but at the same time also maintains or protects the country itself in order to be utilized by the society.

\section{CONCLUSION}

Based on the results of research that the author does, it can be drawn conclusion as follows:

Sasi is a prohibition to harvest certain resources (marine and terrestrial biomass) within the time set. Sasi is intended to regulate all the land (land and water) available in the country, either their own yard or plantation or lading area (commercial), all will get the same treatment.

Customary law is very effective because with the existence of this customary law, the people do not dare to take natural resources before the open time of sasi. It is the fact that both of this law that is customary law and positive law have a position that are interconnected with each other. So these two laws can be used to protect the existing natural resources.

The impact of customary law and positive law is that indigenous peoples can obtain satisfactory marine products as long as there is a sasi close on all marine products are prohibited to be taken until it is open and also with the regulations, the natural resources and environment can be well preserved.

With the existence of marine sasi which is still retained in the village of Eti subdistrict of Seram, the western part of Seram, then it can be directly preserved natural resources in order not to become extinct and can be used by the next generation. The link between sanctions still being used in eti village with environmental sustainability which has an impact on the potential of marine natural resources in this case sea cucumbers. With the sasi therefore the welfare of the people are fulfilled because the products of the sea can be utilized by all villagers.

\section{REFERENCES}

[1] Departemen Pendidikan dan Kebudayaan Pusat penelitian Proyek Penelitian dan Pencatatan Kebudayaan Daerah (1977/1978 ). "Adat dan Upacara Perkawinan."

[2] Frank L Cooley, Mimbar dan Tahta, (Jakarta: Pustaka Sinar Harapan, 1987), hal.189.

[3] Lammerburu, Ellias. "Peran Sasi Sebagai Model Pengelolaan Sumber Daya Alam Pulau-pulau Kecil diKabupaten Maluku Tenggara Barat." Makalah Mahasiswa Program Pasca Sarjana, Fakultas Teknologi Kelaut an, Jurusan Teknik dan Manajemen Pantai, Institut Teknologi Surabaya. 2008.

[4] Lokolo," Hukum Sasi Di Maluku ( Suatu Potret Bina Mulia Lingkungan pedesaan Yang dicari Pemerintah)" Orasi Ilmiah Pada Dies Natalis Universitas Pattimura, tahun 1988, hal.4

[5] Surjono Sukanto, Hukum Adat Indonesia. Divisi Buku Perguruan Tinggi. (Jakarta: PT. Raja Grafindo Persada, 2002),

[6] W. Pattinama, dan M. Patipelohy,"Upacara Sasi ikan lompa di Negeri Haruku," Kementrian Kebudayaan dan Pariwisata Balai Kajian Sejarah dan Nilai tradisional Ambon, 2003 hal. 4

[7] Yones. K. Pellokila dan R. Yando Zakaria, Panduan Bekerja Sama dengan Masyarakat Adat. (Bandung: BSP Kemala, 1998) 